Hind T Jarjees BDS, MSc (Lec)

Khawla M Awni BDS, MSc (Lect)

Enas T Muhseen BDS, MSc (Asst Lect)

\section{An Evaluation of the Integumental Facial Pro- file and It's Relation to Underlying Structures}

\author{
Dept of Pedod, orthod, and Prev Dentistry \\ College of Dentistry, University of Mosul
}

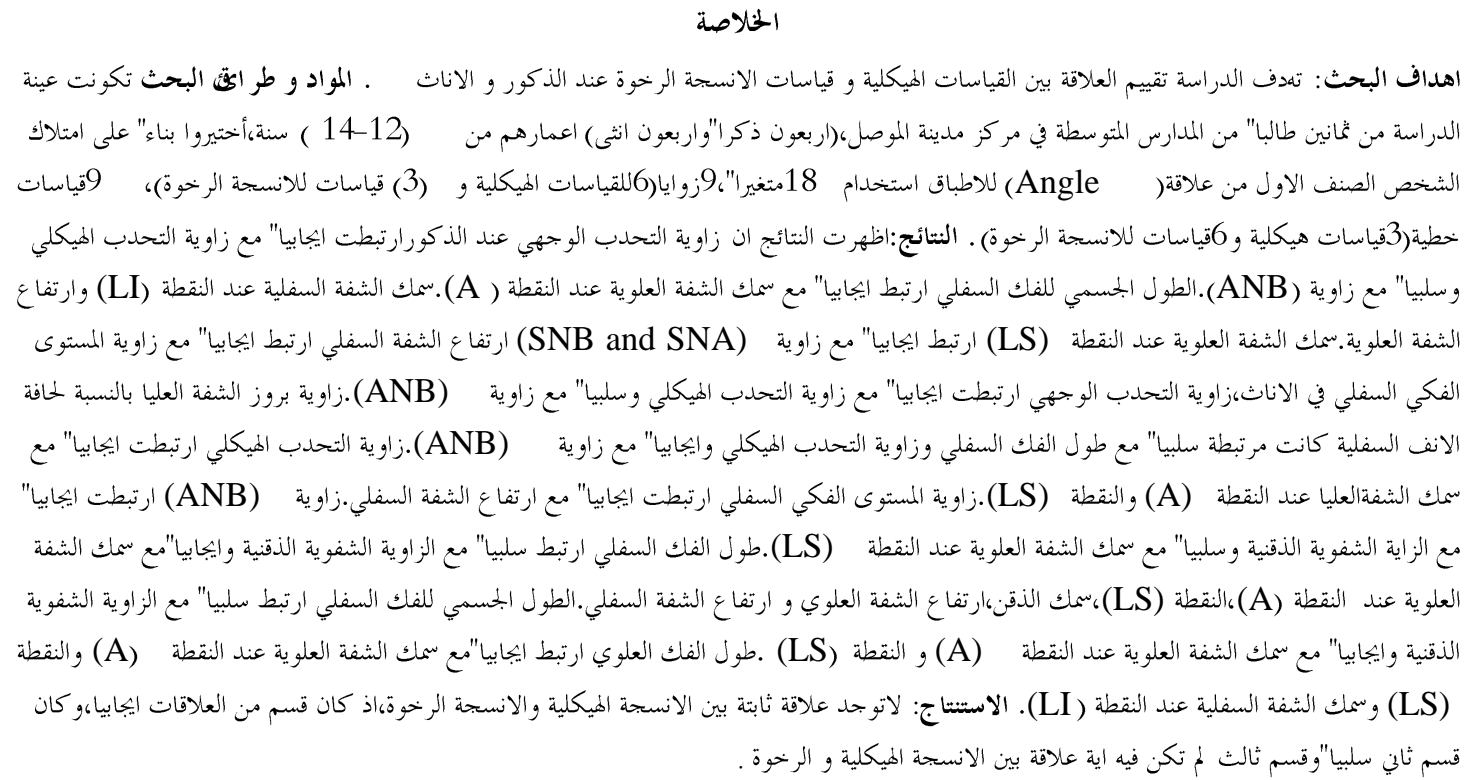

ABSTRACT

Aims : To evaluate the correlations between the skeletal measurements and soft tissue measurements in males and females. Materials and Methods: Eighty students (40 males and 40 females) were selected aged (12-14) years with class I normal occlusion from intermediate schools in Mosul City . A standardized lateral cephalometric radiograph was taken for each student, eighteen variables, 9 angular (6 skeletal and 3 soft tissue ) and 9 linear (3 skeletal and 6 soft tissue) were used in this study. Results: In males, angle of facial convexity positively correlated with angle of skeletal convexity and negatively with the angle describes the relationship of the maxillary and mandibular bases in the sagittal planes. The length of mandibular corpus was positively correlated with upper lip thickness, lower lip thickness at labral inferius and upper lip height. Upper lip thickness at labral superius was positively correlated with angle defines the anteroposterior position of maxilla in relation to anterior cranial base and angle indicates the anteroposterior position of the mandible in relation to the anterior cranial base.Lower lip height was positively correlated with the mandibular plane angle .In females, angle of facial convexity was positively correlated with angle of skeletal convexity and negatively with the angle describes the relationship of the maxillary and mandibular bases in the sagittal planes. The angle measures the protrusion of upper lip relative to the inferior border of the nose was negatively correlated with angle of skeletal convexity and mandibular length and positively with angle describes the relationship of the maxillary and mandibular bases in the sagittal planes.Angle of skeletal convexity was positively correlated with upper lip thickness at point A and upper lip thickness at labral superius. The mandibular plane angle was positively correlated with lower lip height. The angle describes the relationship of the maxillary and mandibular bases in the sagittal planes was positively correlated with labiomental angle and negatively with upper lip thickness at labral superius. The mandibular length was negatively correlated with labiomental angle and positively with upper lip thickness at point A , 
upper lip thickness at labral superius, lower lip thickness, soft tissue thickness at the chin , upper lip height and lower lip height. The length of the mandibular corpus was negatively correlated with labiomantal angle and positively with upper lip thickness at point A and upper lip thickness at labral superius .The length of the maxilla was positively correlated with upper lip thickness at point A, upper lip thickness at labral superius and lower lip thickness. Conclusions:There were no consistend correlations between soft and hard tissue structures, some are positively correlated others are negatively correlated and some of them are completely independent.

Key words : Facial profile, Cephalometric norms.

Jarjees HT, Awni KM , Muhseen ET. An Evaluation of the Integumental Facial Profile and It's Relation to Underlying Structures. Al-Rafidain Dent J. 2011; 11(1):194-201.

Received: 17/11/2009 Sent to Referees: $17 / 11 / 2009$

Accepted for Publication: 23/3/2010

\section{INTRODUCTION}

A major orthodontic treatment goal is to improve facial esthetics and maintain or improve the labial contours of the upper and lower lips. ${ }^{(1,2)}$

Facial and dental esthetics has become even increasingly important during the last decade. Recently, the field of orthodontics has experienced a paradigm shift to focus more on esthetics, with specific emphasis on soft tissues around the mouth. Evaluation of facial esthetics is considered to be subjective, because balance and harmony of facial components do not necessarily mean an attractive face. ${ }^{(3)}$

Judge race or ethnicity and patient race or ethnicity and sex significantly influence lay person's standards for lip profile esthetics, ${ }^{(4,5)}$ also the facial appearance is fundamental for communication and interaction with the environment. ${ }^{(6)}$

One of the most important components of orthodontic diagnosis and treatment planning is the evaluation of the patient's soft tissue profile. ${ }^{(7)}$

A harmonious soft tissue profile, an important treatment goal in orthodontics is sometimes difficult to achieve, partly because the soft tissue overlying the teeth and bones is highly variable in it's thickness. These variations result not only from imbalance of the dental and skeletal structures but from individual variations in the thickness and tension of the soft tissues. ${ }^{(8)}$ Attempts to gain lip closure made by patients with protrusion of the maxillary or mandibular incisors result in lip strain accompanied by hyperactive mentalis function and evaluation of the integument of the chin . orthodontic treatment improves lip form and increases the soft tissue chin thickness. ${ }^{(9,10)}$
Traditionally, it has been assumed that facial contours primarily the result of underlying hard tissue positioning and the subsequent soft tissue drape . Numerous studies are available that illustrate the fact that soft tissues vary considerably in thickness and undergo changes that are regionally independent of hard tissue growth. ${ }^{(11,12)}$

Configural relationships among the constituent features of a face can influence about external facial proportions. ${ }^{(13)}$

The two aspects of soft tissue assessment which have received the most attention are the relationships between the soft tissue and dentoskeletal variables in normal occlusion and the changes in soft tissue associated with therapeutic changes in dentoskeletal structures. ${ }^{(14)}$

Soft tissues might have their own inherent architecture and that the midfacial soft tissue form and position appear to be less dependent on underlying hard tissues than for the lower facial soft tissue variables. ${ }^{(15)}$

Blanchette et al. ${ }^{(11)}$ concluded that the soft tissue attempt to compensate for extremes in vertical skeletal support in those persons with low and short vertical facial patterns. ${ }^{(11)}$

Kasai ${ }^{(8)}$ reported that a longer lower facial height and protruded lower incisors were associated with a thicker upper lip and soft tissue B, and that a larger ANB angle was associated with thicker soft tissue chins. ${ }^{(8)}$ Cephalometric analysis has proven to be a useful tool in the diagnosis, evaluation and treatment planning of patients undergoing orthodontic treatment and / or orthognathic surgery and to evaluate treatment results. ${ }^{(16)}$ The aim of the study was to evaluate the correlations 
between the skeletal and soft tissue measurements in males and females.

\section{MATERIALS AND METHODS}

The sample of this study was collected from intermediate schools in the center of Mosul City. 80 students (40 males and 40 females) were selected aged (12-14) years with class I normal occlusion.

The criteria of sample selection :

1.Full complement of permanent teeth excluding the third molars and normal occlusion with bilateral class I molar and canine relationships. ${ }^{(17)}$

2.Not more than $2 \mathrm{~mm}$ crowding. ${ }^{(17)}$

3. Normal overjet and overbite (1-4 mm). (18)

4.Minor rotations and / or spacing (less than $1 \mathrm{~mm}) .{ }^{(19)}$

5.No previous orthodontic treatment, maxillofacial or plastic surgery. ${ }^{(20)}$

Each subject was radiographed in a standing position by positioning the subject's head in the cephalostat with the left side of the face toward the $\mathrm{x}$-ray tube.The head was then adjusted so that the Frankfort horizontal plane is parallel to the floor.Each subject was instructed to close the teeth in maximum intercuspation with the lips in contact and not to move until exposure was completed.

The lateral cephalometric radiographs from the selected individuals were traced, and reference points and planes were then obtained, 9 angular $(6$ skeletal and 3 soft tissue) and 9 linear (3 skeletal and 6 soft tissue ) measurements illustrated in Figures (1) and (2) were constructed .

* Skeletal measurements :

Angular skeletal measurements include :

FH/NPog : Facial angle : It is formed by the intersection of the Frankfort horizontal and facial plane. ${ }^{(21)}$ NAPog : Angle of convexity. ${ }^{(8)}$

$\mathrm{FH} / \mathrm{GoMe}$ : This is a measure of the relationship between the Frankfort plane and the lower border of the mandible. ${ }^{(21)}$ SNA, SNB, ANB. ${ }^{(22)}$

*Linear skeletal measurements : Ar-Gn, ${ }^{(23)}$ Go-Gn, ${ }^{(24)}$ ANS- PNS. ${ }^{(25)}$

*Soft tissue measurements :

- Angular measurements:

-GL'SNPog : Angle of facial convexity. ${ }^{(26)}$
-CMSNLS : This angle measure the protrusion of upper lip relative to the inferior border of the nose. ${ }^{(23)}$

-LISMPog : Labiomental angle : from labral inferius to soft tissue supramental B and soft tissue pogonion. ${ }^{(27)}$

*Linear measurements :

-ULTHICKA : Upper lip thickness at point A (A-A') : This was measured between point $\mathrm{A}$ and projected $\mathrm{A} .^{(11,23)}$

-ULTHICKLS : Upper lip thickness at labrale superius (LS- LS') : This was measured between labrale superius and projected labrale superius. ${ }^{(11,23)}$

-LLTHICKLI : Lower lip thickness (LILI') . It was measured between labrale inferius and projected labrale inferius. ${ }^{(11,23)}$

-CHIN : Soft tissue thickness at the chin (Pogs-Pogs') : This was measured between soft tissue pogonion and projected soft tissue pogonion. ${ }^{(11,23)}$

- ULHEIGHT : Upper lip height : This was measured as the perpendicular distance from stomion superius to the palatal plane. ${ }^{(28)}$

- LLHEIGHT : Lower lip height : This was measured as the perpendicular distance from stomion inferius to the mandibular plane (Go-Me). ${ }^{(28)}$

Analysis of data by using SPSS program was done including descriptive statistics (means and standard deviations) of the skeletal and soft tissue variables (angular and linear measurements) for males, females and total sample.

Pearson's correlation coefficients between skeletal and soft tissue variables were done for males and females separately. The " $\mathrm{r}$ " value is described as significant at $(p \leq 0.05)$ and highly significant at $(\mathrm{p} \leq 0.01)$.

\section{RESULTS}

Tables $(1,2)$ show the descriptions of the skeletal and soft tissue variables (angular and linear measurements) for both sexes and total sample. The correlation coefficients of the soft tissue with skeletal variables for males and females were described in tables $(3,4)$. Some of them showed a positive correlation s, while others showed a negative one. 
Table (1):The description of the skeletal variables (angular and linear measurements), means and SD for males, females and total sample.

\begin{tabular}{ccccc}
\hline variables & sex & mean & SD & NO. \\
\hline \multirow{2}{*}{ FH/NPog* } & M & 87.53 & 2.34 & 40 \\
& $\mathrm{~F}$ & 88.19 & 2.51 & 40 \\
& $\mathrm{~T}$ & 88 & 2.42 & 80 \\
NAPog* & $\mathrm{M}$ & 173.67 & 3.38 & 40 \\
& $\mathrm{~F}$ & 174.03 & 3.79 & 40 \\
& $\mathrm{~T}$ & 174 & 3.60 & 80 \\
FH/GoMe* & $\mathrm{M}$ & 26.70 & 4.69 & 40 \\
& $\mathrm{~F}$ & 25.79 & 3.74 & 40 \\
& $\mathrm{~T}$ & 26 & 4.21 & 80 \\
SNA* & $\mathrm{M}$ & 82.70 & 3.36 & 40 \\
& $\mathrm{~F}$ & 82.15 & 3.27 & 40 \\
& $\mathrm{~T}$ & 82 & 3.29 & 80 \\
SNB $^{*}$ & $\mathrm{M}$ & 78.95 & 3.26 & 40 \\
& $\mathrm{~F}$ & 78.56 & 2.90 & 40 \\
& $\mathrm{~T}$ & 79 & 3.1 & 80 \\
ANB* & $\mathrm{M}$ & 3.79 & 1.31 & 40 \\
& $\mathrm{~F}$ & 3.58 & 1.45 & 40 \\
& $\mathrm{~T}$ & 4 & 1.44 & 80 \\
Ar-Gn** & $\mathrm{M}$ & 113.69 & 12.38 & 40 \\
& $\mathrm{~F}$ & 110.36 & 4.56 & 40 \\
& $\mathrm{~T}$ & 111 & 5.17 & 80 \\
Go-Gn** & $\mathrm{M}$ & 78.54 & 4.32 & 40 \\
& $\mathrm{~F}$ & 76.85 & 3.16 & 40 \\
& $\mathrm{~T}$ & 78 & 3.89 & 80 \\
ANS-PNS** & $\mathrm{M}$ & 54.36 & 2.35 & 40 \\
& $\mathrm{~F}$ & 53.53 & 1.79 & 40 \\
& $\mathrm{~T}$ & 54 & 2.17 & 80 \\
\hline
\end{tabular}

*angular measurements (degrees). SD:standard deviation.**linear measurements (mm).

NO.:number; FH/NPog : Facial angle; NAPog : Angle of convexity; FH/GoMe : mandibular plane angle; Ar-Gn: mandibular length; Go-Gn: mandibular body length; ANS-PNS: maxillary length. 
Table (2): The description of the soft tissue variables (angular and linear measurements), means and SD for males, females and total sample.

\begin{tabular}{|c|c|c|c|c|}
\hline variables & sex & mean & SD & NO. \\
\hline \multirow{4}{*}{ GL'SNPog* } & $\mathrm{M}$ & 162.13 & 4.09 & 40 \\
\hline & $\mathrm{F}$ & 164.31 & 5.18 & 40 \\
\hline & $\mathrm{T}$ & 163 & 4.75 & 80 \\
\hline & $\mathrm{M}$ & 108.03 & 7.02 & 40 \\
\hline \multirow[t]{3}{*}{ CMSNLS* } & $\mathrm{F}$ & 107.43 & 8.06 & 40 \\
\hline & $\mathrm{T}$ & 108 & 7.49 & 80 \\
\hline & $\mathrm{M}$ & 127.51 & 9.87 & 40 \\
\hline \multirow[t]{3}{*}{ LISMPog* } & $\mathrm{F}$ & 130.06 & 8.20 & 40 \\
\hline & $\mathrm{T}$ & 129 & 9.40 & 80 \\
\hline & $\mathrm{M}$ & 17.03 & 1.83 & 40 \\
\hline \multirow{3}{*}{ ULTHICKA $* * *$} & $\mathrm{~F}$ & 15.78 & 1.78 & 40 \\
\hline & $\mathrm{T}$ & 16.39 & 1.88 & 80 \\
\hline & $\mathrm{M}$ & 14.91 & 1.99 & 40 \\
\hline \multirow[t]{3}{*}{ ULTHICLS** } & $\mathrm{F}$ & 13.51 & 1.93 & 40 \\
\hline & $\mathrm{T}$ & 14 & 2.1 & 80 \\
\hline & $\mathrm{M}$ & 16.09 & 1.95 & 40 \\
\hline \multirow[t]{3}{*}{ LLTHICLI** } & $\mathrm{F}$ & 14.51 & 1.68 & 40 \\
\hline & $\mathrm{T}$ & 15 & 2.06 & 80 \\
\hline & $\mathrm{M}$ & 13.74 & 1.53 & 40 \\
\hline \multirow[t]{3}{*}{ CHIN** } & $\mathrm{F}$ & 13.11 & 1.85 & 40 \\
\hline & $\mathrm{T}$ & 13 & 1.71 & 80 \\
\hline & $\mathrm{M}$ & 26.28 & 2.47 & 40 \\
\hline \multirow[t]{3}{*}{ ULHEIGHT** } & $\mathrm{F}$ & 24.76 & 2.12 & 40 \\
\hline & $\mathrm{T}$ & 26 & 2.4 & 80 \\
\hline & $\mathrm{M}$ & 46.81 & 3.56 & 40 \\
\hline \multirow[t]{2}{*}{ LLHEIGHT $* *$} & $\mathrm{~F}$ & 44.91 & 2.92 & 40 \\
\hline & $\mathrm{T}$ & 46 & 3.37 & 80 \\
\hline
\end{tabular}

*angular measurements (degrees). SD: standard deviation.**linear measurements (mm). NO.: number; GL'SNPog : Angle of facial convexity; CMSNLS : nasolabial angle; LISMPog : Labiomental angle; ULTHICKA : Upper lip thickness at point A; ULTHICKLS : Upper lip thickness at labrale superius; LLTHICKLI : Lower lip thickness; CHIN : Soft tissue thickness at the chin; ULHEIGHT : Upper lip height; LLHEIGHT : Lower lip height.

Table (3): The correlation coefficients of the soft tissue with skeletal variables for males.

\begin{tabular}{cccccccccc}
\hline & FH/NPog & NAPog & FH/GoMe & SNA & $\begin{array}{c}\text { SN } \\
\text { B }\end{array}$ & ANB & $\begin{array}{c}\text { Ar- } \\
\text { Gn }\end{array}$ & $\begin{array}{c}\text { Go- } \\
\text { Gn }\end{array}$ & $\begin{array}{c}\text { ANS- } \\
\text { PNS }\end{array}$ \\
\hline GL'SNPog & -.07 & $.69 * *$ & -.31 & -.29 & -.04 & $-.65^{* *}$ & -.03 & -.17 & -.29 \\
CMSNLS & -.20 & .08 & .18 & -.27 & -.25 & -.10 & -.05 & -.06 & .10 \\
LISMPog & -.20 & .08 & .18 & -.27 & -.25 & -.10 & -.05 & -.06 & .10 \\
ULTHICKA & .08 & .27 & .04 & .19 & .31 & -.29 & .15 & $.42^{* *}$ & .31 \\
ULTHICKLS & .26 & .01 & -.16 & $.34^{*}$ & .37 & & & & \\
LLTHICKLI & .07 & -.09 & .01 & .21 & .18 & .10 & .11 & $.45^{* *}$ & .26 \\
CHIN & -.02 & -.29 & .23 & .15 & .05 & .26 & .05 & .01 & .16 \\
ULHEIGHT & -.25 & .11 & .26 & -.24 & -.19 & -.17 & .04 & $.42^{* *}$ & .02 \\
LLHEIGHT & -.16 & -.22 & $.63 * *$ & .03 & -.03 & .15 & .23 & .30 & .14
\end{tabular}

*significant at $p \leq 0.05$, **significant at $p \leq 0.01$; GL'SNPog : Angle of facial convexity; CMSNLS : nasolabial angle; LISMPog : Labiomental angle; ULTHICKA : Upper lip thickness at point A; ULTHICKLS : Upper lip thickness at labrale superius; LLTHICKLI : Lower lip thickness; CHIN : Soft tissue thickness at the chin; ULHEIGHT : Upper lip height; LLHEIGHT : Lower lip height. 
Table(4): The correlation coefficients of the soft tissue with skeletal variables for females.

\begin{tabular}{cccccccccc}
\hline & FH/NPog & NAPog & FH/GoMe & SNA & SNB & ANB & Ar-Gn & Go-Gn & $\begin{array}{c}\text { ANS- } \\
\text { PNS }\end{array}$ \\
\hline GL'SNPog & .07 & $.63^{* *}$ & -.28 & -.19 & .13 & $-.71^{* *}$ & .27 & .21 & -.01 \\
CMSNLS & -.16 & $-.52^{* *}$ & .18 & .30 & .03 & $.60^{* *}$ & $-.34^{*}$ & -.18 & -.11 \\
LISMPog & -.07 & -.26 & 016 & .07 & -.09 & $.33^{*}$ & $-.51^{* *}$ & $-.35^{*}$ & -.26 \\
ULTHICKA & .18 & $.35^{*}$ & -.03 & -.13 & .002 & -.30 & $.63^{* *}$ & $.45^{* *}$ & $.46^{* *}$ \\
ULTHICKLS & .16 & $.36^{*}$ & .10 & -.23 & -.09 & $-.35^{*}$ & $.50^{* *}$ & $.33^{*}$ & $.43^{* *}$ \\
LLTHICKLI & -.001 & .04 & .19 & .00 & .01 & -.01 & $.45^{* *}$ & .31 & $.43^{* *}$ \\
CHIN & -.02 & .20 & -.09 & -.26 & -.15 & .28 & $.46^{* *}$ & .24 & .22 \\
ULHEIGHT & .03 & -.13 & .25 & -.03 & -.09 & .10 & $.37^{*}$ & .22 & .19 \\
LLHEIGHT & .03 & .06 & $.44^{* *}$ & -.10 & -.15 & .09 & $.39^{*}$ & .23 & -.02 \\
\hline
\end{tabular}

*significant at $p \leq 0.05$, **significant at $p \leq 0.01$. GL'SNPog : Angle of facial convexity; CMSNLS : nasolabial angle; LISMPog : Labiomental angle; ULTHICKA : Upper lip thickness at point A; ULTHICKLS : Upper lip thickness at labrale superius; LLTHICKLI : Lower lip thickness; CHIN : Soft tissue thickness at the chin; ULHEIGHT : Upper lip height; LLHEIGHT : Lower lip height.

In males, as shown in Table (3) GL'SNPog was positively correlated with NAPog and negatively with ANB angles.Go-Gn line was positively correlated with ULTHICKA, LLTHICKLI and ULHEIGHT.ULTHICKLS was positively correlated with SNA and SNB angles.LLHEIGHT was positively correlated with $\mathrm{FH} / \mathrm{GoMe}$.In females, as shown in Table (4) GL'SNPog was also positively correlated with NAPog and negatively with ANB .While CMSNLS was negatively correlated with NAPog and Ar-Gn and positively with ANB angle. Furthermore, the NAPog was positively correlated with ULTHICKA and ULTHICKLS. FH/GoMe was positively correlated with LLHEIGHT.ANB was positively correlated with LISMPog and negatively with ULTHICKLS .Ar-Gn was negatively correlated with LISMPog and positively with ULTHICKA, ULTHICKLS, LLTHICKLI, CHIN, ULHEIGHT and LLHEIGHT.Go-Gn was negatively correlated with LISMPog and positively with ULTHICKA and ULTHICKLS. ANSPNS was positively correlated with ULTHICKA, ULTHICKLS and LLTHICKLI.

\section{DISCUSSION}

NAPog was highly significant and positively correlated with the GL'SNPog in males and females, in addition it's positively correlated with the CMSNLS ,ULTHICKA and ULTHICKLS in females only .

The relation of angle of convexity NAPog with the convexity of soft tissue profile similar to the results achieved by berglind et al. ${ }^{(16)}$

This mean that the convexity of the soft tissue profile is closely related to the underlying NAPog .FH/GoMe angle was highly significant and positively correlated with the lower lip height in both sexes . The soft tissues attempt to compensate for extremes in vertical skeletal support in those persons with long and short vertical facial patterns ,the boys and girls with long vertical patterns showed a greater vertical height of the lower lip when compared with those of short vertical patterns, also the vertical height of the lower lip has been a compensatory mechanism for the subjects to perform a lip seal. ${ }^{(11)}$

The SNA and SNB angles are significant and positively correlated with ULTHICKLS in males only which comes in agreement with Kasai ${ }^{(8)}$ who stated that the relation ships between upper and lower jaw were associated with the thickness of the upper lip and of soft tissue chin. The differences between males and females is due to the differences develop in the size , thickness and position of the lips and chin as they approach maturity . ${ }^{(29)}$

Nanda ${ }^{(30)}$ found that female's upper lip thickness and chin soft tissue decreased with age, but the lower lip increased. These soft tissue changes in females, taken together with the minor mandibular skeletal changes resulted with age and the profile not becoming straighter .

Concerning ANB angle, our results showed that this angle was highly significant and negatively correlated with 
GL'SNPog angle in both sexes, this angle also positively correlated with CMSNLS and LISMPog angles and negatively with ULTHICKLS in females only,due to the structural and growth differences between males and females.

Our results showed that as the ANB angle increase, the skeletal facial convexity will decrease, so that GL'SNPog which is the angle of soft tissue convexity will decrease and vise versa.

Kasai ${ }^{(8)}$ stated that the ANB angle provide orthodontists with important information and a small ANB angle will increase the facial convexity and associated with a smaller pogonion thickness and a relatively thick upper lip.

The Ar-Gn line has no significant correlation with the soft tissue variables in males, while in females it was significantly negatively correlated with CMSNLS and LISMPog and positively with ULTHICK A, ULTHICKLS, LLTHICKLI, CHIN , ULHEIGHT and LLHEIGHT.

The relationship of the lower jaw and the upper lip and soft tissue chin are similar to that found by Kasai. ${ }^{(8)}$

Go-Gn line is highly significant and positively correlated with ULTHICKA, LLTHICKLI and ULHEIGHT in males, while in females it is negatively correlated with LISMPog and positively with ULTHICKA and ULTHICKLS.

The relationship between the length of the mandibular corpus and lip thickness are present to provide a more normal facial appearance. ${ }^{(11)}$

ANS-PNS has no significant relationship with the soft tissue variables in males , while in females it was highly significant and positively correlated with ULTHICKA , ULTHICKLS and LLTHICKLI.Increasing the maxillary length in females will lead to increase in the thickness of upper and lower lips.The maxilla maintained a constant relationship and presented a co-ordinated forward displacement relative to the cranial base.The maxilla is at least two years a head in its relative size in comparison to the mandible,in preadolescent females. ${ }^{(25)}$

In general, there were no consistent, good correlations between soft tissue structures and the underlying hard tissue structures. ${ }^{(23)}$ There are many correlation of the hard and soft tissue variables demonstrated a considerable degree of variability between males and females the reason is unknown. ${ }^{(31)}$

\section{CONCLUSION}

The relationships between the hard tissue structures and soft tissue profiles are variable. For some variables, hard and soft tissue structure are closely related (positively or negatively), but some are independent because the characteristics of the soft tissues are influenced by their length, thickness, and functional aspects such as tissue tension.

\section{REFERENCES}

1. Tadic $\mathrm{N}$ and Woods MG.Incisal and soft tissue effects of maxillary premolar extraction in class II treatment.Angle Orthodontist. 2006;77(5):808-816.

2. Timothy FF and Peter GD.Soft tissue profile changes in late adolescent males.Angle Orthodontist. 1997;67 (5) : 373-380.

3. Altaki A, Oguz F and Abuhijleh E. Facial soft tissue values inperian adults with normal occlusion and well - balanced faces. Angle Orthodontist.2008; 79 (3): 491494.

4. Mayumi N, Etsuko M, John PH, Peter TG, Peter MN, John D, Rugh and Hidehara. Esthetic preferences of European American , Hispanic American, Japanese, and African Judges for soft tissue profiles.Am J Orthod Dentofacial Orthop.2009;135 (4) Supp 1: S87-S95.

5. Hwang HS, Kim SW and Mcnamara AJ.Ethnic differences in the soft tissue profile of Korean and European - American adults with normal occlusions and well- balanced faces .Angle Orthodontist. $2002 ; 72(1): 72-80$.

6. Vander Geld P, Oosterveld, Van Heck G, Kuijpers-Jagtman AM.Smile attractiveness .Angle Orthodontist.2007; 77: 759-765.

7. Mc Namara JA, Brust EW and Riolo ML.Soft tissue evaluation of individuals with an ideal occlusion and a well balanced face.In : Mc Namara JA, ed. Esthetics and the treatment of facial form. Monograph 28, craniofacial growth series .Ann Arbor, Mich: center for human 
growth and development, the university of Michigan .1992; 115-146.

8. Kasai K.Soft tissue adaptability to hard tissues in facial profiles .Am J Orthod Dentifacial Orthop.1998; 113(6): 674-684.

9. Lo FD and Hunter WS . Changes in nasolabial angle related to maxillary incisor retraction .Am J Orthod Dentofacial Orthop. 1982 ; 82(5): 384-91.

10.Singh RN. Changes in the soft tissue chin after orthodontic treatment. Am J Orthod Dentofacial Orthop . 1990 ; 98(1): 41-6.

11.Blanchette M, Nanda RS , Currier GF, Ghosh $\mathrm{J}$ and Nanda SK. Alongitudinal cephalometric study of the soft tissue profile of short and long face syndromes from 7 to 17 years . Am J Orthod Dentofacial Orthop.1996; 109(2) : 116-131.

12.Fervario VF, Sforza C, Miani A and Pizzini G.A size standardized analysis of soft tissue facial profile during growth.Am J Orthod Dentofacial Orthop.1997; 112(1): 28-33.

13.Sofia MK, Demetrios JK and Meropin NS. Configuration of facial features influences objective evaluation of facial type. Am J Orthod Dentofacial Orthop.2008; 133(2): 277-282.

14.Saxby $\mathrm{PhJ}$ and Freer UJ .Dentoskeletal determinants of soft tissue morphology .Angle Orthodontist .1985; 55(2) :147-154.

15.Moseling KP and Woods MG .Lip curve changes in females with premolar extraction or non extraction treatment. Angle Orthodontist.2004;74(1): 51-62.

16.Johannsdottr B, Thordarson A and Magnusson ThE. Craniofacial skeletal and soft tissue morphology in Icelandic adults.European $\quad J \quad$ Orthod. 2004; 26(3):245-250.

17.Bishara SE , Jackobsen JR, Hession TJ and Treder JE .Soft tissue profile changes from 5-45 years of age .Am J Orthod Dentofacial Orthop.1998; 114(6): 698-706.

18.Rukujarit T, Ratanyatikul C, Godfrey K and Deesqmur S.Lateral cephalometric norms for 12-14 years Thai girls and boys in Khon Kaen with an acceptable profile . Khon Kaen Univ Dent J. 2001; 6(1): 7683.

19.Axelsson S, Kjaer I , Bjornland $\mathrm{T}$ and Storhang K.Longitudinal cephalometric standards for the neurocranium in Norwe- gians from 6 to 21 years of age. Eur J Orthod .2003;25: 185-198.

20.Bishara SE. Longitudinal cephalometric standards from 5 years of age to adulthood .Am J Orthod Dentofacial Orthop.1981; 79(1): 35-44.

21.Downs WB .Variation in facial relationships : Their significance in treatment and prognosis.Am J Orthod . 1948 ; 34: 811840.

22.Steiner CC . Cephalometric for you and me .Am J Orthod .1953; 39 (10): 729-755.

23.Nanda RS , Meng H, Kapila S and Goorhuis J.Growth changes in the soft tissue facial profile. Angle Orthodontist . 1990; 60 (3): 177- 190.

24.Nanda RS .The rates of growth of several facial components measured from serial cephalometric roentgenograms.Am J Orthod. 1955; 41: 658-673.

25.Nanda SK. Differential growth of the female face in the anteroposterior dimention .Angle Orthodontist. 1992; 62(1): 2334.

26.Manchamp O and Sassouni V.Growth and prediction of the skeletal and soft tissue profiles.Am J Orthod. 1973 ; 64(1): 83-94.

27.Zylinsiki GC, Nanda RS and Kapila S.Analysis of soft tissue facial profile in white males . Am J Orthod Dentofacial Orthop.1992; 101(6): 514-8.

28. Mamandras AH.Linear changes of the maxillary and mandibular lips.Am J Orthod Dentofacial Orthop.1988; 94(5): 405410.

29. Riolo ML, Moyers RE, Tenhore TR and Moyers CA.Facial soft tissue changes during adolescence. In : Craniofacial growth during adolescence. Edited by David SC and Latherine AR.University of Michigan center of human growth and development , Ann Arbor.1987; 117-33.

30.Nanda RS and Merrill RM. Cephalometric assessment of sagittal relationship between maxilla and mandible.Am J Orthod Dentofacial Orthop.1994; 105(4): 328-344.

31.D Aloisio D and Pangraxio - Kulbersh V.A comparative and correlation study of the cranial base in North American blacks . Am J Orthod Dentofacial Orthop.1992; 102(5): 449-55. 